\title{
The Prince and the Scholar: A Study of Two Multiple-Text Manuscripts from Fifteenth and Sixteenth Centuries Morocco
}

\begin{abstract}
Manuscripts Arabe 248 and 788 of the Escorial collection are multipletext manuscripts (MTMs) produced in Morocco, the former in 1409, the latter in 1561. Although they share a certain amount of texts, probably because these were part of the contemporary curriculum, the analysis of both MTMs shows that they were prepared with precise and different aims.
\end{abstract}

\section{The scholar's companion}

In Arabic manuscript libraries, manuscripts with collections of texts are well represented, but their typology is wide-ranging. One of the kinds of collection covered are the multiple-text manuscripts (MTMs). These collections offered a practical solution at the time by affording convenient access to a set of texts which were particularly interesting to either the copyist or the person who commissioned the copying. As works were selected with a view to transcription by the same person, they were very different from composite volumes which consisted of previously copied texts that circumstance had placed in the hands of a single owner, who then decided to bind them into the same volume. Medieval librarians were familiar with the specific problems posed by the classification of these volumes, be they of one type or another, and treated them differently from multi-volume works which they handled in an entirely different manner.

Because the creation of an MTM was a specific intellectual undertaking, studying it can afford new insight into the interests of the person behind the project, whether he was the designer and creator, or the commissioner. At the El Escorial library, two volumes of this type were produced in a Moroccan context, but with almost a century between them. The first is the Escorial Arabe 788 manuscript

The research leading to these results has received funding from the European Research Council under Horizon 2020 framework Grant Agreement no. 670628, project 'SICLe (Saadian Intellectual and Cultural Life)'. I would like to thank the librarian of the San Lorenzo monastery at El Escorial, P. Jose Luis del Valle Merino, for having facilitated my research on the Arabic manuscripts for which he is responsible. 
(Figs 1-4), a 227-folio copy in quarto format, with folios covered by dense, tiny Maghribi writing of 38 to 41 lines per page. The hand is not particularly neat, which suggests a copy for personal use, as does a note appearing at the head of the manuscript, to which we will return later. In addition to the texts pertaining to the copyist's and owner's initial plan, the manuscript contains a number of notes and certificates, filling almost all the spaces that remained empty upon completion of the copy.

The explicits of the various works in this volume are almost systematically followed by colophons that indicate the dates of completion, ranging from 25 Ramadān 811/11 February 1409 to 14 Jumādā II 812/24 October 1409. The paper used in the manuscript, which is of Western make, is very much the same throughout: watermarks in the shape of a unicorn head are found at various points in the volume. Another type of paper was nevertheless also used and can be recognized by the different structure of the wire lines. This was most likely due to the way in which the work was carried out-an aspect that we will examine further on. The name of the copyist does not appear in any of the colophons, and his identification depends on other elements present in the manuscript, particularly a note that currently appears at the beginning. On fol. $5 \mathrm{r}$, halfway up the page above a text box to which we will return, and under a sort of table of contents, the copyist slipped in a note equivalent to a colophon where he identified himself as Muhammad b. 'Abd al-'Azīz b. Muhammad al-Ṣanhājīî' and indicated that he had made the copy 'for himself and for whosoever God wishes after him'; followed by the date of 1st Sha'bān 812/9 December $1409 .{ }^{2}$

The copyist, who is known through other sources, seemed to have had a taste for precision, as he indicated the date on which the copying of 18 of the 23 texts comprising the MTM was completed, which is relatively uncommon for Arabic manuscripts. We therefore know that the manuscript still existed in the form of separate quires on 14 Jumādā II 812/24 October 1409. On this date, the copyist completed the transcription of the last text, no. 7, in the copy's final order. The 'colophon' from fol. 5r, dated 1st Sha 'bān 812/9 December 1409, may indicate the date on which the copyist, having dedicated several weeks to correcting the copy, finally organized the quires.

1 He is known thanks to biographical dictionaries like Ibn Zaydān 2008, III, 689-690; see also Aḥmad Bābā al-Tunbuktī 2000, 523, or Ibn Ghāzī al-Miknāsī 2006, 119-120.

2 The year is indicated in rūmi numerals: the shape of the unit digit (2) is different from that more commonly found, but it corresponds to what is observed in colophons where the date is expressed in full letters. 
Judging from its style, the binding is from the Saadian period (late sixteenth or early seventeenth century). The state of the margins, notably the coloured bookmarks indicating the beginning of the texts, suggests that it was redone at this time. Later on, probably at the end of the nineteenth century, an attempt was made to repair the folds of damaged quires, which may have resulted in the disappearance of certain clues. The presence of marks indicating the middle of the quire, which may be contemporary with the Saadian binding, allows us to confirm that the key features of the quires have remained the same.

The colophons that indicate the date enable us to follow the transcription process. The chronology is therefore as follows: ${ }^{3}$
a) 17 Ramadāan 811/3 February 1409
$6 \mathrm{a}$
b) 25 Ramadāan 811/11 February 1409
c) 22 Shawwāl 811/10 March 1409

\section{1}
d) 9 Dhū al-hijja 811/25 April 1409
e) 24 Dhū al-ḥijja 811/9 May 1409
f) 14 Muharram 812/29 May 1409
g) 21 Muḥarram 812/5 June 1409
12
h) 13 Ṣafar 812/27 June 1409
$6 \mathrm{~b}$
i) 15 Ṣafar 812/29 June 1409
j) 24 Safar 812/8 July 1409
k) $3 \mathrm{Rabi}^{-\mathrm{I}} \mathrm{I} 81<2>/ 16$ July 1409
l) $1<2>\operatorname{Rabi}^{`}$ I $812 / 25$ July $1409 \quad 18$
m) $18 R^{R a b i ` \mathrm{I} ~ 812 / 31 \text { July } 1409} 19$
n) $1<9>R^{2} a b^{-c}$ I 812/1st August $1409 \quad 20$
o) 18 Jumādā I 812/28 September $1409 \quad 10$
p) 21 Jumādā I 812/1st October 1409
q) 9 Jumādā II 812/19 October 1409
r) 14 Jumādā II 812/24 October 1409

The comparison of this data with the structure of the quires provides some insight into how Muhammad b. 'Abd al-'Azīz worked. He followed the dominant usage in the Muslim world in general and in the Maghreb in particular at the time, by preferentially using quinions, which make up three quarters of the volume with 17 in total, sometimes with one extra folio to fit in the end of a text, as we find in the case of no.

3 The current position of each textual unit within the manuscript is indicated by a number, in front of its date of completion. I kept H. Dérenboug's numbering as it appears in his catalogue (Dérenbourg 1903, 74-81), except for a small change about text no. 6 which is actually composed of two distinct treatises by the same author. They were transcribed separately but put together when the volume was bound. 
10. He nonetheless occasionally also used shorter quires for shorter works. For example, no. 3 is contained in a seven-page quire on fols 76-82, nos 16 and 17 are combined in a binion on fols 203-206; in other cases, a smaller quire receives the end of a text, as is the case on fols 129-134, where a ternion was used by the copyist to finish no. 5. This way of adjusting quires to textual units is probably at the origin of the use of isolated folios, recognizable by the stubs that can be seen in the fold of the quires. ${ }^{4}$

\begin{tabular}{|c|c|c|c|c|c|}
\hline Quires & No. & Begins at & Ends at & Peculiarities & Date \\
\hline $\begin{array}{l}?(4)+V+1 \\
(15)\end{array}$ & 1 & $5 \mathrm{v}$ & $15 v$ & & $10 / 03 / 1409$ \\
\hline $6 \mathrm{~V}(75)$ & 2 & $16 r$ & $75 v$ & & $11 / 02 / 1409$ \\
\hline III+1 (82) & 3 & $76 r$ & $82 v$ & $76 r$ : note & $16 / 07 / 1409$ \\
\hline $\begin{array}{l}3 \mathrm{~V}(112) \\
\text { IV-2 (118) }\end{array}$ & 4 & $83 v$ & $118 r$ & $\begin{array}{l}83 \mathrm{r} \text { : note and exlibris } \\
118 \mathrm{r} \text { : collation note }\end{array}$ & $25 / 04 / 1409$ \\
\hline $\begin{array}{l}\text { V (128), III } \\
(134)\end{array}$ & 5 & $118 \mathrm{v}$ & $134 \mathrm{v}$ & & $9 / 05 / 1409$ \\
\hline \multirow[t]{2}{*}{$\begin{array}{l}\text { V (144), II } \\
\text { (148) }\end{array}$} & $6 a$ & $135 \mathrm{v}$ & $138 r$ & $\begin{array}{l}\text { 135r: note } \\
138 \mathrm{r}: \text { certificate }\end{array}$ & $3 / 02 / 1409$ \\
\hline & $6 b$ & $138 v$ & $\begin{array}{l}148 \mathrm{r} \\
148 \mathrm{v} \\
\text { blank }\end{array}$ & 148r: certificate & $27 / 06 / 1409$ \\
\hline \multicolumn{6}{|l|}{$\begin{array}{l}\text { fol. } 149 \text {, } \\
\text { addition }\end{array}$} \\
\hline II (153) & 7 & $150 v$ & $154 r$ & 150r: note & $24 / 10 / 1409$ \\
\hline IV+1 (162), & 8 & $154 \mathrm{v}$ & $158 v$ & 154r: certificate & $29 / 05 / 1409$ \\
\hline \multirow[t]{2}{*}{ V+1 (173) } & 9 & $159 v$ & $167 v$ & 159r: certificate & $8 / 07 / 1409$ \\
\hline & 10 & $168 v$ & $173 r$ & 168r: blank & $28 / 09 / 1409$ \\
\hline II+1 (178) & 11 & $174 \mathrm{v}$ & $175 r$ & $175 v$ : poem & $1 / 10 / 1409$ \\
\hline
\end{tabular}

4 The description of the quires (see Gacek 2009, 336) has been divided in order to evidence the relationship between the quires and the texts. When the folio numbers corresponding to the beginning or the end of a text are not on the same line as its number, this means that they are in a quire where another text is also found. Due to the shortness of the last treatises, this presentation could not be maintained as many of them were transcribed on the same quire. In the description the Roman numeral indicates the kind of quire (V= quinion, III= ternion, etc.); the number between parenthesis is the number of the last folio in a sequence whereas the number eventually found before the Roman numeral gives the number of quires evidencing the same typology (e.g.: $6 \mathrm{~V}$ means six quinions). 


\begin{tabular}{|c|c|c|c|c|c|}
\hline Quires & No. & Begins at & Ends at & Peculiarities & Date \\
\hline & & & & $\begin{array}{l}176 r-v: \text { certificate } \\
177 \mathrm{r}: \text { poem } \\
177 \mathrm{v}-178 \mathrm{r} \text { : certificate } \\
178 \mathrm{v} \text { : notes }\end{array}$ & \\
\hline \multirow[t]{5}{*}{$\begin{array}{l}2 \mathrm{~V}(198), \mathrm{II} \\
(202)\end{array}$} & 12 & $179 v$ & $191 \mathrm{r}$ & $\begin{array}{l}\text { 179r: notes } \\
\text { 191r: certificate }\end{array}$ & $5 / 06 / 1409$ \\
\hline & 13 & $191 v$ & $193 r$ & & $29 / 06 / 1409$ \\
\hline & 14 & $193 v$ & $197 r$ & & s.d. \\
\hline & 15 & $197 \mathrm{r}$ & $200 \mathrm{v}$ & & s.d. \\
\hline & 16 & $198 v$ & & 201r-203r: notes & s.d. \\
\hline \multirow[t]{2}{*}{ II (206) } & 17 & $203 v$ & $205 r$ & & s.d. \\
\hline & 18 & $205 r$ & $205 v$ & $205 v-207 r$ : notes & s.d. \\
\hline \multirow[t]{3}{*}{ V (216) } & 19 & $207 v$ & $212 r$ & 212r: facsimile & $25 / 07 / 1409$ \\
\hline & 20 & $212 v$ & $214 \mathrm{v}$ & $214 \mathrm{v}$ : collation note & $31 / 07 / 1409$ \\
\hline & 21 & $215 v$ & $216 v$ & $215 \mathrm{r}:$ verses & $1 / 08 / 1409$ \\
\hline \multirow[t]{3}{*}{$V+1(227)$} & 22 & $217 v$ & $223 r$ & $\begin{array}{l}217 \mathrm{r} \text { : certificate } \\
223 \mathrm{r} \text { : certificate and } \\
\text { collation note }\end{array}$ & $19 / 10 / 1409$ \\
\hline & 23 & $223 v$ & $225 r$ & & s.d. \\
\hline & 24 & $225 \mathrm{v}$ & $225 \mathrm{v}$ & $\begin{array}{l}225 \mathrm{v} \text { : certificate } \\
226-227 \mathrm{v} \text { : varia }\end{array}$ & s.d. \\
\hline
\end{tabular}

The fact that two (or more) texts with sequential completion dates appear after one another in the manuscript does not mean that they were transcribed on the same quire or on a coherent sequence of quires. The quinion of fols 207 to 216 effectively contains the three texts nos 18 to 20, which were copied in sequence at the end of July and the beginning of August 1409. The transcription of text no. 5 was completed on 24 Dhü al-hiija 811/9 May 1409, or in other words, immediately following no. 4. According to the colophons' calendar, no. 5 starts on the reverse side of the last folio (fol. 118v) of the four quires that the copyist had just used for copying no. 4. However, texts nos 10 and 11, which were completed with a three-day intermission, are in two different quires.

Even though there were three exceptions (nos 2, 15 and 17), Muhammad b. 'Abd al-'Azìz usually, and in keeping with the custom, copied the incipit on the verso of a folio, due to which the folios' rectos at the beginning of the texts were generally left blank. At times, the copyist reused this space to finish a transcrip- 
tion when it was compatible with his project. The most remarkable example of this is text no. 7, which was the last text and was copied on 14 Jumādā II 812/24 October 1409. Its last lines appear on fol. 154r, which was left blank at the beginning of a quire that had been used five months earlier. Likewise, the copyist had planned to subsequently transcribe texts nos $6 \mathrm{a}$ and $6 \mathrm{~b}$, which were both by the same author. In February, he used the first four sheets of a quinion (fols 135 to 138) and then, in June, the last six sheets, adding a binion (fols 145 to 148) to complete his work.

Muhammad b. 'Abd al-'Azīz mostly copied isolated works, accumulating independent fascicles as he went along. Although he decided on the content, the sequence of his work must have depended on external circumstances such as the availability of the models, for instance. Ultimately, the works as presented in the current form of the volume were organized by Muhammad b. 'Abd al'Azìz according to a very clear thematic structure, albeit after 14 jumādā II 812/24 October 1409, when the copying of text no. 7 was completed.

1. 5v-15v: Abū al-Faḍl 'Iyāọ b. 'Iyāọ al-Yahsibī al-Sabtī (d. 544/1149), maybe his K. al-ilam bi-ḥudud qawāid al-islām (Fig. 1). ${ }^{5}$

2. 16r-75v: Khalīl b. Ișhāạ b. Mūsā al-Mālikī al-Miṣrī (d. 767/1365), al-Mukhtaṣar. ${ }^{6}$

3. 76v-82v: Abū Iṣhāạq Ibrāhīm b. Abū Bakr al-Tilimsānī (d. 690/1291), al-Urjuza fi al-farā'ị̣. ${ }^{7}$

4. 83v-118r: 'Uthmān b. 'Umar b. Abū Bakr Ibn al-Ḥājib (d.646/1249), Mukhtașar alMuntahā al-su'āl wa-l-amal fi 'alami al-ușūl wa-l-jadl. ${ }^{\circ}$

5. 118v-134v: Jamāl al-dīn Muḥammad b. 'Abd al-Raḥmān al-Qazwīnī (d. 739/1338), Talkhịṣ al-miftăh. ${ }^{9}$

6. 135v-148r: Abū al-Qāsim al-Qāsim b. Firrūh b. Khalak al-Shātịī (d. 590/1194), Hiirz alamānī wa-wajh al-tahānī (fols 135v-138r) ${ }^{10}$ and Qāșida al-rā'iyya (fols 138v-148r). ${ }^{11}$

5 See GAL I, 370, no. 6; $S$ I, 630. In the index prepared by the copyist on fol. 5 r, the title is: 'Qawâ 'id of <Qādīi 'Iyāộ'.

6 See GAL II, 84; $S$ II, 96.

7 See GAL I, 385/10. Dérenbourg $(1903,75)$ thought that the author was 'Afif al-dīn Sulaymān

b. 'Alī al-Tilimsānī.

8 See $G A L$ I, 306/viii; $S$ I, 537.

9 See GAL I, 295; $S$ I, 516.

10 The Hirz al-amānī is a versified version of al-Dānī's Taysīr called in the index al-Shātibiyya al-kubrā (see GAL I, 409/i; $S$ I, 725).

11 Or al-Shāțibiyya al-ṣughrā, see GAL I, 410/ii and S I, 726. 


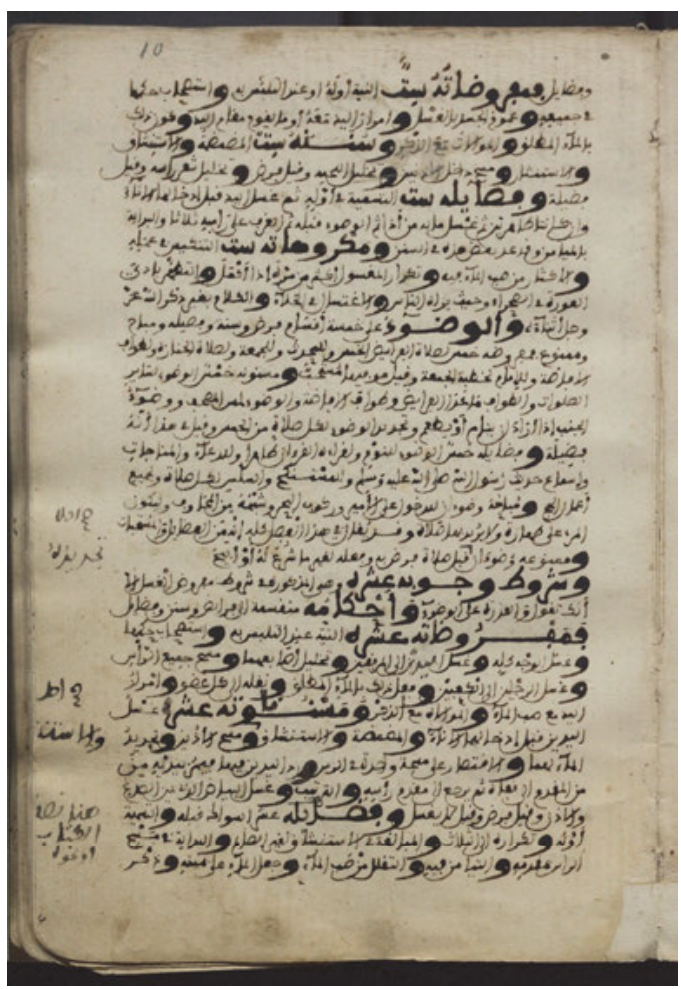

Fig. 1: Arabe 788, fol. 10r. Abū al-Faḍl 'lyāọ̣ b. 'Iyāọ al-Yahsibī al-Sabtī (d. 544/1149), maybe his K. al-illam bi-ḥudud qawāiid al-islām. (C) El Escorial

7. 150v-154r: 'Abdallāh b. Yūsuf b. 'Abdallāh b. Yūsuf b. Aḥmad b. 'Abdallāh Ibn Hishām (d. 761/1360), Qațr al-nadā wa-ball al-șadā. ${ }^{12}$

8. $154 \mathrm{v}-158 \mathrm{v}$ : by the same author, al-I'rāb 'an qawā'id al-i'rāa ${ }^{13}$

9. 159v-167v: Jamāl al-dīn Muhammad b. 'Abdallāh b. Muhammad b. 'Abdallāh Ibn Mālik al-Ṭā'ī al-Jayyānī (d. 672/1273), al-Alfiyya. ${ }^{14}$

10. 168v-173r: Abū 'Abdallāh Muhammad b. 'Alī b. Khālid Ibn al-Saqqāṭ (sixth/eleventh century), K. Ikhtiṣār al-'arūẹ. ${ }^{15}$

11. 174v-175r: Diyā al-dīn abū Muhammad 'Abdallāh b. 'Uthmān al-Khazrajī (fl. towards 650/1252), al-Rāmiza al-shāfiyya fí 'ilm al-'arūḍ (Fig. 2). ${ }^{16}$

12 See $G A L$ II, 23/1; $S$ II, 16-17.

13 See GAL II, 24; $S$ II, 18.

14 See GAL I, 298/4-ii, $S$ I, 522.

15 See $G A L$ I, 282/1; $S$ I, 495. 


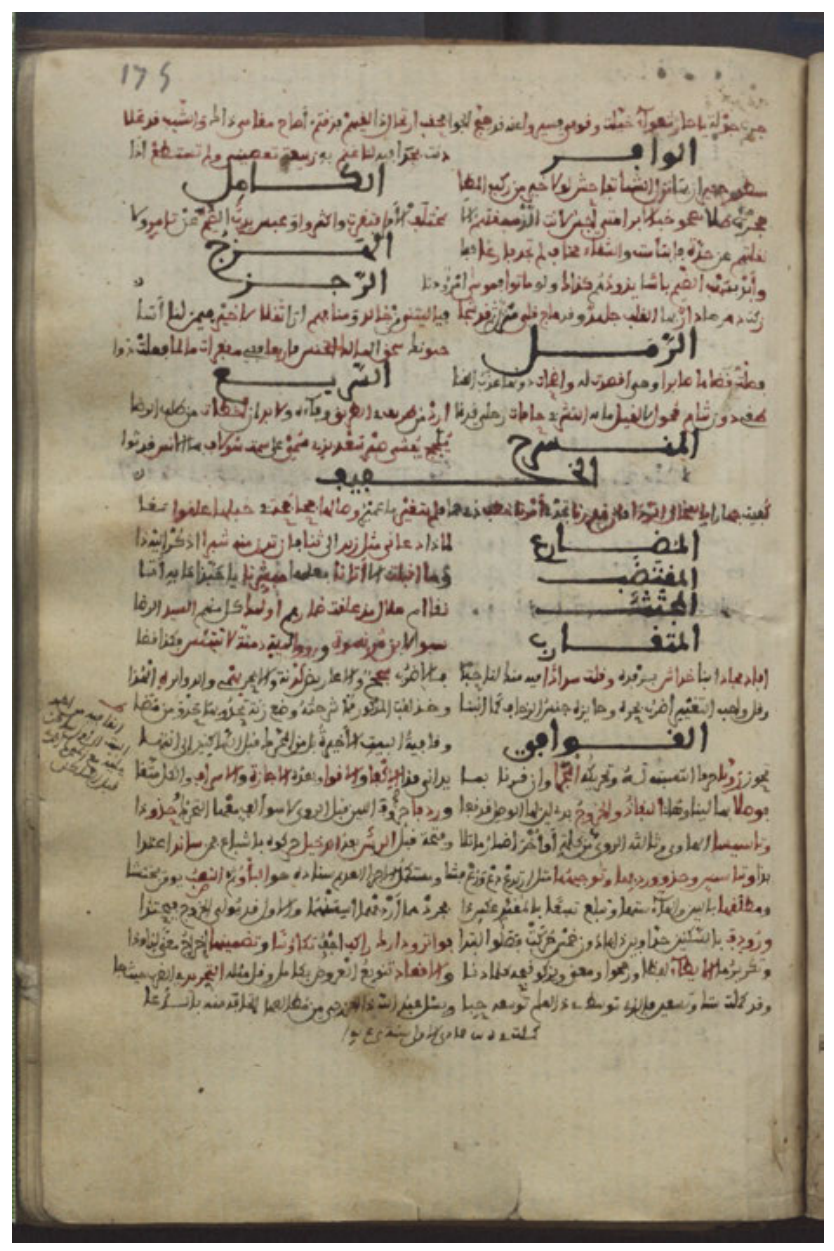

Fig. 2: Arabe 788, fol. 175r. Ḍiyā al-dīn abū Muḥammad 'Abdallāh b. 'Uthmān al-Khazrajī (fl. towards 650/1252), al-Rāmiza al-shāfiyya fí 'ilm al-arūọ. (@ El Escorial

12. 179v-191r: Rajaz on medecine by Ibn Sīnā. ${ }^{17}$

13. 191v-193r: Abū Mūsā Hārūn b. Ișhāq Ibn 'Azrūn (c. 500/1106), Tadhȳ̄l urjūza Ibn Sīnā..$^{18}$

14. 193v-197r: Abū Bakr Muhammad b. Zākariyya al-Rāzī (d. 313/925), excerpts. ${ }^{19}$

16 See GAL I, 312/10; $S$ I, 545.

17 I was unable to identify the text.

18 See $S$ I, 823/81. 
15. 197r-198v: Ḥunayn b. Iṣhāa al-'Ibādī (d. 260/873), excerpts. ${ }^{20}$

16. 198v-200v: Choice potions and remedies.

17. 203v-205r: Abū al-'Abbās Aḥmad b. Muhammad b. 'Uthmān Ibn al-Bannā' (d. 721/1321), maybe his Qānūn li-tarhīl al-shams wa-l-qamar fi al-manāzil wa-ma'rifa awqāt al-layl wa-l-nahar. ${ }^{21}$

18. 205r-205v: Muhammad b. Aḥmad al-'Azafì (fl. c.633/1256), poem on the Persian months. $^{22}$

19. 207v-212r: Ibn al-Bannā' (d. 721/1321), Talkhīṣ fí 'amal al-ḥisāb. ${ }^{23}$

20. 212v-214v: Afụal al-dīn Muḥammad b. Nāmwar b. 'Abd al-Malik al-Khūnajī (d. 646/1248), al-Jumal. ${ }^{24}$

21. 215v-216v: Burhān al-din Muḥammad b. Muḥammad al-Nasafì, al-Burhāniyya. ${ }^{25}$

22. 217v-223r: Abū al-Faḍl Aḥmad b. Muḥammad Ibn 'Ațā' Allāh al-Iskandarī (d. 709/1309), al-Hikam (al- 'Ațā'iyya). ${ }^{26}$

23. 223v-225r: Muhạmmad b. Ibrāhīm Ibn 'Abbād al-Rondī (d. 796/1394), al-Du'ā bi-lasmā' al-ḥusnā. ${ }^{27}$

24. 225v: Abū al-Ḥasan 'Alī b. 'Abdallāh b. 'Abd al-Jabbār al-Ḥasanī al-Shādhilī (d. 656/1258), Hizb al-baḥr (Fig. 3). ${ }^{28}$

25. 226r-v: Venerable orisons and morals.

19 About the author, see GAL I, 233; $S$ I, 417. On fol. 197r is a short extract from al-Majūsī's $K$. Kāmil al-șinā'a al-țibbiyya (d. 384/994; GAL I, 237/17) that is not indicated in the index.

20 About the author, see GAL I, 205. Muhammad b. 'Abd al-'Aziz seems to have mistaken him for Yuhannā (sic!) b. Māsawayh, whose name appears on fol. 197r (see $S$ I, 416). The information in the index on fol. $5 \mathrm{r}$ should probably be corrected in this way. Moreover, Dérenbourg grouped that with what could look like a development of the latter in the index prepared by Muhammad b. 'Abd al-'Azìz. Actually, the title 'Choice potions and remedies' (no. 16) is separated from the previous one ('Hunayn's Fușūl', no. 15) and from the next one ('Qānūn on the hours by Ibn al-Bannā', no. 17) by the same red punctuation as that found between the various entries in the index.

21 See GAL II, 255/6.

22 See $S$ I, 626.

23 See $G A L$ I, 255/1; $S$ I, 363.

24 See $G A L$ I, 463/21; $S$ I, 838.

25 H. Dérenbourg identifies thus the author (Dérenbourg 1903, 80: 'paraît être'). See GAL $S$ I, 849 (also GAL I, 467, no. 28).

26 See $G A L$ II, 118/11; $S$ II, 146.

27 See GAL II, 118; $S$ II, 146.

28 See $G A L$ I, 449; $S$ I, 805/5. 


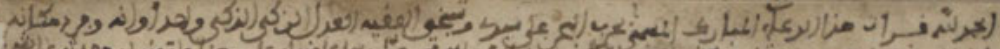
\&.

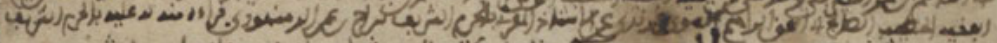

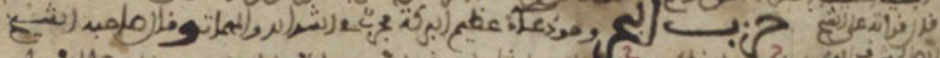

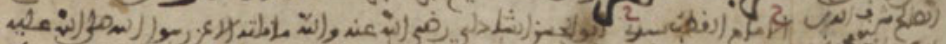

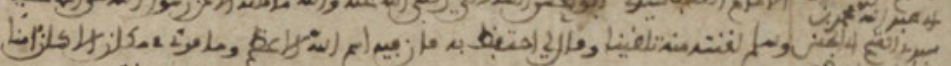

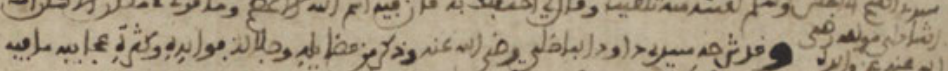

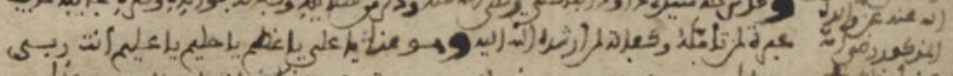
عناف

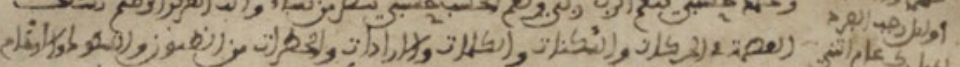
ئمبا:

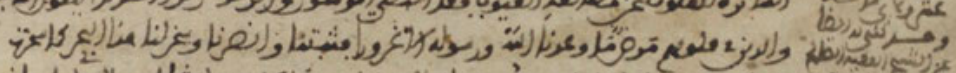

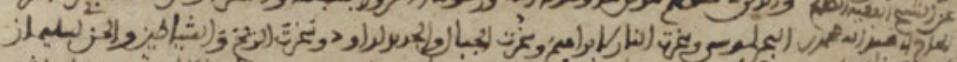
年

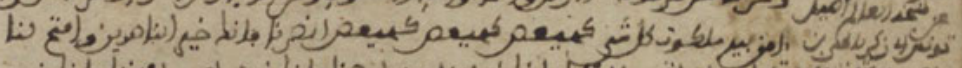

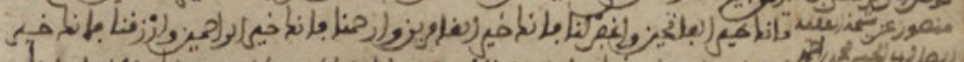
.

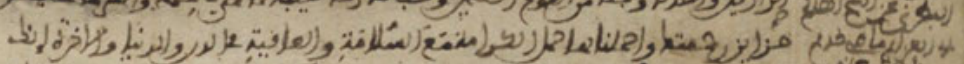
.

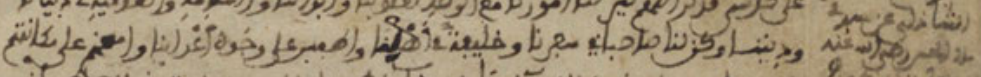

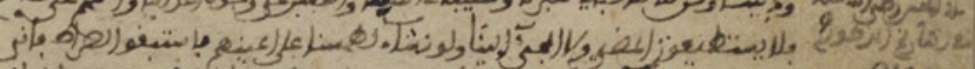

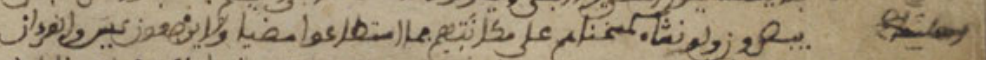

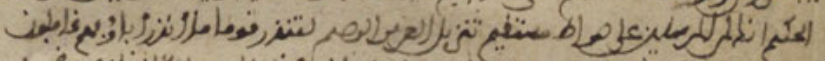

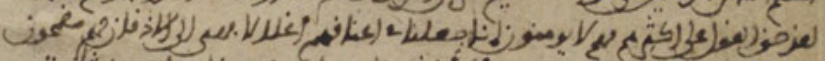

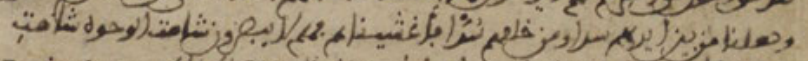

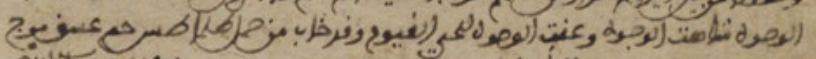

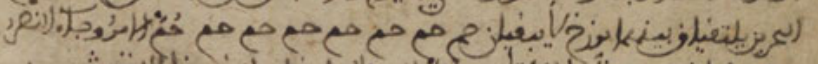
بـ

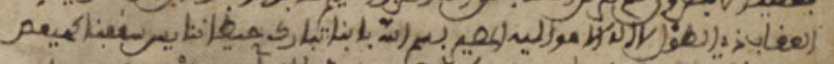

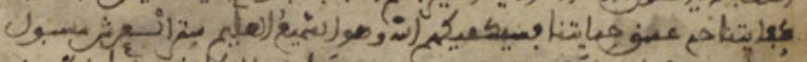

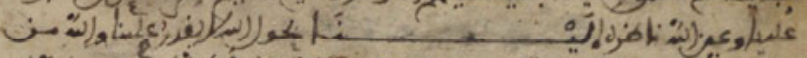

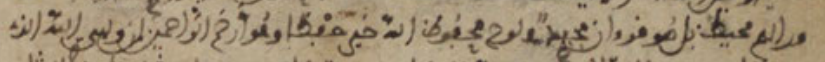

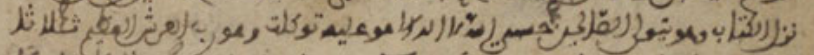

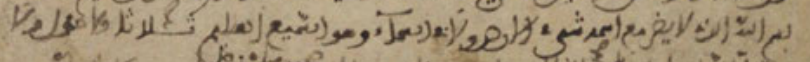

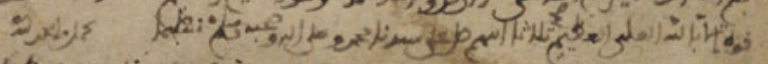

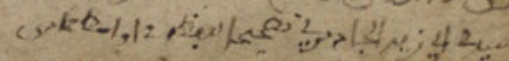

Fig. 3: Arabe 788, fol. 225v: Abū al-Ḥasan 'Alī b. 'Abdallāh b. 'Abd al-Jabbār al-Ḥasanī alShādhilī (d. 656/1258), Ḥizb al-baḥr. (C) El Escorial 


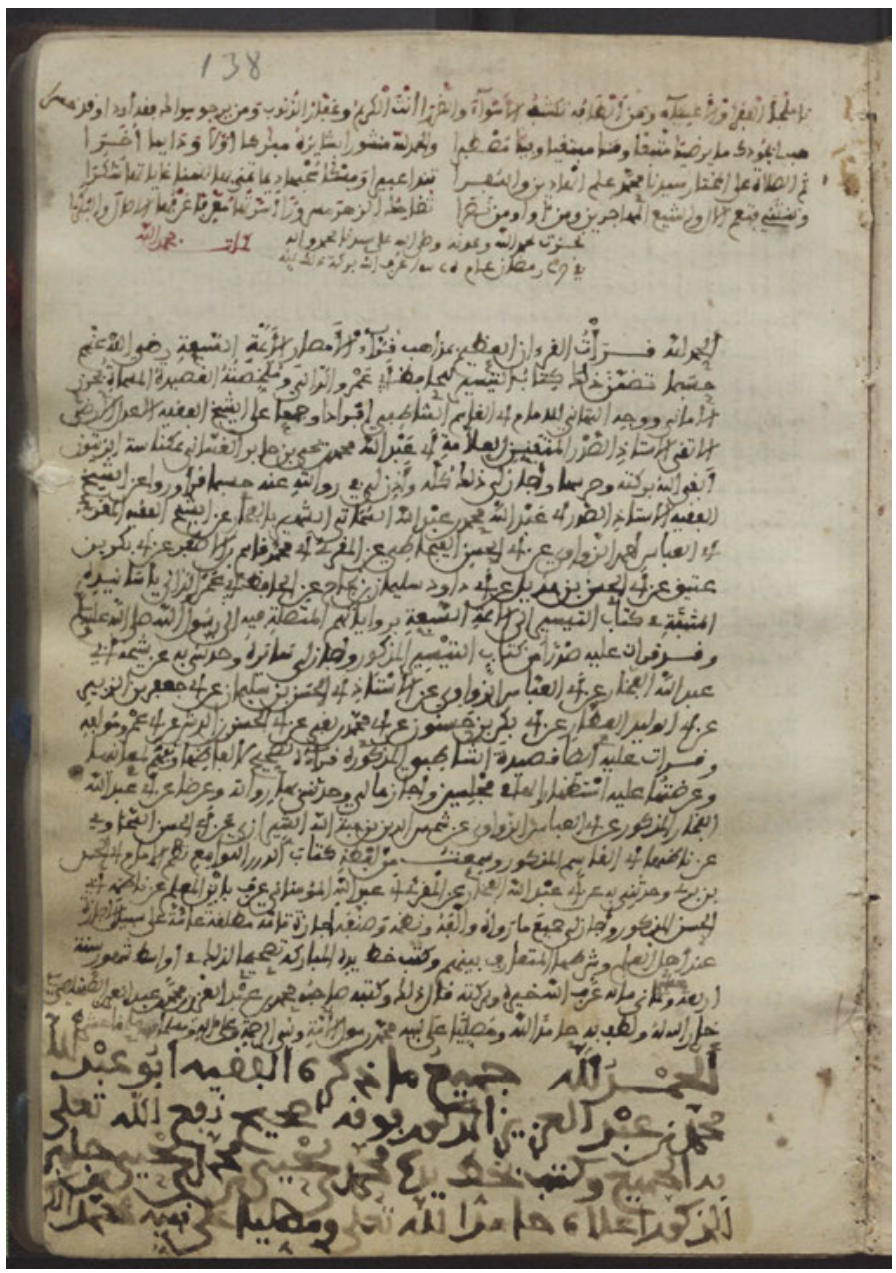

Fig. 4: Arabe 788, fol. 138r, Muḥammad b. 'Abd al-'Azīz al-Șanhājī. C El Escorial

After a text that discusses the principles of the Islamic faith, the Qawã id by Qādī 'Iyāọ (no. 1), there are three treatises on Malikite law (nos 2-4). Rhetoric and grammar make up the following sections (nos 5 and then 7-9), although they are interrupted by two versified treatises by al-Shātibī on the text of the Qur'ān (nos 6a and $6 \mathrm{~b}$, Fig. 4). To these were added the following two texts on prosody (nos 10-11). The distinguishing feature of the MTM created by Muhammad b. 'Abd al-'Azīz al-Ṣanhājī may be the scientific texts that appear afterwards: medicine (nos 12-16), astronomy in the broad sense (nos 17-18), and mathematics (no. 19). Do the two short treatises 
on logic (nos 20-21) belong to this group? This is not entirely sure. The manuscript closes with texts of a religious and mystical nature (nos 22-25), thus reflecting the interests of a traditional scholar. It is nevertheless distinguished by the inclusion of short treatises on medicine and astronomy in the MTM that he wished to create.

On fol. 5r, the date of 1st Sha'bān 812/9 December 1409 appears. Although it does signal the completion of Muhammad b. 'Abd al-'Azīz al-Ṣanhāì̄'s undertaking to compile the volume of texts, it by no means marks the end of the story of this MTM. As the manuscript accompanied the copyist in the pursuit of his intellectual projects, he gradually filled unused spaces with notes of various kinds. Fol. $5 \mathrm{r}$ contains very important information in this regard, while its appearance is unattractive, to say the least: it is filled with dense writing-containing information that, at different stages, Muhammad b. 'Abd al-'Azīz deemed useful to have available at the head of his codex. He most likely started by drawing up a table of contents across six lines on the upper half of the sheet, followed by the 'colophon' mentioned above. Later, the bio-bibliographic information that progressively filled in the remaining space was added.

Roughly halfway up the page, the copyist at some point wrote four tiny lines in ink, around which he drew a box. As there was no room left to add anything to this short text, he continued it in a gap between the table of contents and the notes occupying the top margin. The three lines that we can read here continue in the margin, between the table of contents and the edge of the folio, across 12 lines of which the left portion has disappeared. Once again, a box has been drawn around this note in ink, which, together with the above-mentioned note, retraces the copyist's itinerary during the years following the copy's completion. We thus learn that he arrived in Ceuta at the end of $\operatorname{Rabi}^{-}$II 815/July 1412, moving on to al-Andalus at the end of Jumā dā II / beginning of October 1412. He disembarked in Malaga and headed for Almería. From there, he set sail again for Tunis and then reached Alexandria in mid-Dhü al-qa'da/16 February of that same lunar year. Once in Egypt, he went to Cairo, where he remained for five months before heading north at the beginning of Jumādā II 816/September 1413. He passed through Jerusalem and reached Damascus in Rajab/October 1413. Aside from a pilgrimage to Mecca, he spent more than a year in the city before returning to the Maghreb via Cairo and Alexandria at the end of Dhū al-hijja 817/mid-March 1415.

The writing does indeed seem to be that of the copyist, and in addition to the palaeographic argument, there are other documents contained in Arabe 788 from El Escorial that confirm Muhammad b. 'Abd al-'Aziz's trip to the Near East on the dates indicated. The travel roughly outlined here is reflected in a series of reading and audition certificates in the name of that same Muhammad b. 'Abd al-'Aziz alSanhājī, with the exception of one certificate that is attributed to a different scholar. 
Muhammad al-Ṣanhāij̄'s training-and most likely his intellectual undertakings-started before he began to copy the first texts of his MTM, and possibly even before he conceived of the idea. In 810/1410, he followed the teachings of Muḥammad b. Aḥmad b. Muḥammad b. Muhammad b. abū Bakr Ibn Marzūq in Fez, ${ }^{29}$ obtaining an ijazza (licence) from him for texts that do not appear in the volume. In fact, according to a certificate found on fols $177 \mathrm{v}-178 \mathrm{r}$, at the time, this master transmitted the two Șaḥị̣ to him, namely those by al-Bukhārī and Muslim, as well as Mālik's Muwatțā'. ${ }^{30}$ These were actually only portions of those works and the form of the certificate is particular; it may be a copy of another older certificate, which is clearly the case of a document that appears on fol. 212r and which reproduces the colophon, and a certificate that appears in the manuscript which served to collate the text of the Talkhiss fi al-ḥisāb (no. 18). ${ }^{31}$ Copying previous certificates was not an uncommon practice; on the other hand, a particularity of our copyist's work consisted in writing certificates within the volume for works that did not appear in it. This tendency was subsequently confirmed.

The first certificates following the completion of the MTM transcription-or almost contemporaneous with it, ${ }^{32}$ are dated to the years $812 / 1409-814 / 1411$, and associated with texts that the copyist had transcribed. The oldest of these, which appears in the margin alongside the beginning of the Hizb al-bahr (fol. 223v, Fig. 3), is dated 1st Rajab 812/18 November 1409. It concerns the famous litany (no. 24 of the MTM), which he read before Abū al-Qāsim b. Muhammad alSayrafi. ${ }^{33}$ This is certainly not a mere coincidence: al-Shādhilì’s litany is directly related to the dangers one faces during travel. The copyist availed himself of this protection before embarking on his journey, which means that his plans were already set in 812/1409, almost three years before he actually left Meknes. The copy may have had an apotropaic value by itself, but more important still is the

29 This Ibn Marzūq (d.14 Sha'bān 842/1439) is the grandson of Muhammad b. Ahmad b. Muḥammad b. Aḥmad b. Muḥammad b. Muḥammad b. Abū Bakr Ibn Marzūq al-Tilimsānī (d. 781/1379; see GAL II, 239). An overview of this family of scholars from Tlemcen can be found in Viguera 1977, 12, and more generally on pp. 11-14.

30 Muhammad b. 'Abd al-'Azīz was known as an expert in Qur'ān recitation and hadìth (see Ibn Zaydān 2008, 689).

31 This text is written in a script quite different from that of Muhammad b. 'Abd al-'Azizz; the colophon indicates the 1st Jumāda II 702/ 21 January 1303 as the date of completion. The ijāza has been given by the author, Ibn al-Bannā', for the Talkhịs fì 'amal al-hisāb as well as for two other treatises. It is dated to the end of Jumādā I 708/towards 15 November 1308.

32 I shall not examine here the detail of the isnād-s or chains of transmission found in the certificates.

33 See above, n. 29. 
fact that, even before his volume was fully completed at the beginning of Sha'bān 812/December 1409, Muhammad b. 'Abd al-'Azīz decided to start his collection of samā' $\bar{a} t$ with the Hizb al-bahr. A second one, located in the bottom margin of the same folio, is dated mid-Jumādā II 813/mid-October 1410 and concerns the same text, which was read before Abū Zayd al-Jādīrī (sic) this time. ${ }^{34}$

A third certificate, dated mid-814/mid-July 1411, also pertains to this phase: it follows the two didactic poems by al-Shātibī (m. en 590/1194), called al-Shātibiyya al-kubrā (Fig. 4) and al-Shätibiyya al-sughrā in the manuscript (nos 6a and b), the first of which is known by the title of Hirz al-amānī wa-wajh al-tahānī. ${ }^{35}$ Following two sessions in Meknes on the date indicated, Muhammad b. 'Abd al-'Azīz received an ijāza with a larger scope, regarding the reciting of the Qur'ān before his master with a reference to al-Dānī’s K. al-taysīr and al-Shātibī’s qașīda. At the bottom of the certificate, a licence is granted for Abū al-Hasan's K. al-durar allawämi.$^{36}$ In this case, the situation is analogous to the one mentioned above, namely that some transmission licences are not related to the contents of the manuscript. Finally, on 29 July 1411, Muhammad b. 'Abd al-'Azīz received an ijāza for Ibn Mālik's Alfiyya (d. 672/1273; text no. 9), which had been transcribed two years earlier (fol. 159r). ${ }^{37}$ We can assume that this took place in Meknes. The certificate is written in the hand of Yahyā b. Aḥmad b. Muhammad al-Anșārī al-Fāsī.

The following certificates are associated with Muhammad b. 'Abd al-'Azīz alȘanhājì's journey to the East. He left Meknes and first arrived in Ceuta, where he completed the collation of Ibn al-Hājib’s Mukhtașar (no. 4) on 9 Jumādā I 815/17 August 1412 (fol. 83r). The following stages of his trip, in Andalus and to Tunis, did not result in any intellectual activities that were recorded in the manuscript. Local intellectual circles appeared once again, from mid-February 1413, during Muhammad b. 'Abd al-'Azīz's stay in Alexandria (fol. 148r) where, on 24 Dhū alhijja 815/27 March 1413, he obtained an ijāza from Muhammad b. Abū Bakr b. 'Umar al-Mālikī for various works for which he already had a licence: the two didactic poems by al-Shāțibī studied in Meknes in 1411 (see fol. 138r; nos 6a and b), a portion of Ibn Mālik's Alfiyya (no. 9), ${ }^{38}$ and a work by Diyā' al-Dīn 'Abd Allāh b. Muhammad al-Makhzūmī, al-Rāmiza fì fann al-'arūẹ wa-l-qawāfì known as al-

34 Abū Zayd 'Abd al-Raḥmān b. Muḥammad b. 'Ațiya al-Maydūnī al-Jādirī (Meknes, 777/13751376-Fez, 818/1415-1416), see Benchekroun 1974, 247-250.

35 GAL I, 409; $S$ I, 725. This could be the 'Aqīla atrāb al-qașā'id fi asna al-maqāṣid (GAL I, 410; $S$ I, 726-727).

36 GAL II, 248; $S$ II, 350. The treatise deals with Nāfi's qirā'a.

37 This is the text no. 9 in the MTM, see n. 15.

38 It is thus a second $i j \bar{a} z a$ for this text. 
Khazrajiyya (no. 11). ${ }^{39}$ The certificate was written in the hand of the master himself, in a clearly Oriental script, whereas Muhammad b. 'Abd al-'Azīz usually wrote these documents himself with a brief note in the hand of the master confirming the accuracy of the information.

After moving on to Cairo, our copyist once again resumed his intellectual activities in the city. First of all, on Tuesday 28 Șafar 816/30 May 1413, he obtained a licence from Shams al-Dīn Abū 'Abd Allāh Muhammad b. 'Alī b. Ja 'far al-Bilālī alMawșili to transmit two of his works, the Hayāt al-Ihyya ' wa-tuhfat al-awliy $\bar{a}^{\prime}$ and a Muqaddima, which is a summary of his Kitāb al-minhāj (fol. 217r). ${ }^{40}$ In addition, at the madrasa associated with al-Manșūrī hospital, ${ }^{41}$ he followed the teaching of Sirāj al-Dīn Abū Hafs 'Umar al-Bahādūrī. The latter issued an ijāza to him for a poem on medicine, Ibn Sīnā's Madkhal al-țibb, ${ }^{42}$ and three other medical treatises, the Fuṣūl al-imām Abūqrāt, the K. al-asbāb wa-l-'alāmāt al-Īlāqiyya, ${ }^{43}$ and alSamarqandiyya (fol. 191r). ${ }^{44}$ On the last day of $R a b i^{`}$ I 816/30 June 1413, at this madrasa, he completed the reading of Tāj al-dīn Aḥmad abī al-Faḍl b. 'Ațā' Allāh's al-Hikam before Abū al-Faḍl Muhammad b. Ibrāhīm al-Tilimsānī: text no. 22 of the volume (fol. 223r). ${ }^{45}$

During the next stage of his travels in the East, in Jerusalem in Jumādā II 816/November 1413, he obtained a licence for the two Șahịh (fol. 176r-v). Once again, the master, Aḥmad b. Muhammad b. 'Ațā' Allāh b. Muhammad al-... [illegible], called Tamr al-Harawi, wrote the certificate, which mentions these two works as well as his own commentary on Muslim's Șahịh. His long stay in Damascus (October 1413 to March 1415) was an opportunity to obtain new licences. He followed the teachings of Sa'd al-Dīn Abū Sa'īd Musā'id b. Sārī b. Mas'ūd al-Hawārī and obtained from this master two authorizations to transmit following the sessions held in 'Aqrabā, in the ghūța of Damascus, and in Damascus itself. The first covers Jamāl al-Dīn Ibn Hishām's I'rāb fì qawā'id al-írāa (no. 8) and dates to 16

39 GAL I, 380/10; $S$ I, 545.

40 As indicated by the title, it is a commentary of al-Ghazalī's Ihyya' 'ulum al-dinn; it is probably the text recorded in the supplement of the Geschichte der Arabischen Litteratur (S I, 749, no. 10), the name of the author being recorded as Muhammad b. 'Alī al-Bilālī al-Ajlūnī.

$41 E I^{2}, \mathrm{IV}, 506$.

42 It may be the poem copied on the preceding folios (fols 179v-191r, no. 12). The certificate is in the hand of Muhammad b. 'Abd al-'Azīz himself, but what follows has been written by his master. 43 The treatise was composed by Muhammad b. 'Alī al-Īlāqī (d. 536/1141), see GAL I, 485; S I, 826. 44 It is probably a work by Abū Ḥāmid Muḥammad b. 'Alī b. 'Umar al-Samarqandī (d. 619/1222); see GAL I, 490-491 and S I, 895-896.

45 See above, n. 26. 
Rabī' I 817/5 June 1414, ${ }^{46}$ while the second, which concerns al-Bukhārì’s Șaḥiḥ, was obtained at the end of $R_{a b i}{ }^{`}$ I 817/c.15 June 1414 (fol. 176v).

Muhammad b. 'Abd al-'Azīz's quest for knowledge did not stop with his departure from the East. The manuscript contains two more documents, dated 818/1415, which corresponded to stages during his return trip that are not signalled in the note on fol. 5r. Our traveller first stopped in Bona/Annaba, where he met with Ibn Marzūq, the master whose teachings he had followed in 810/1410 in Fez. ${ }^{47}$ He then once again attended sessions, after which he wrote a long certificate on fol. $177 \mathrm{v}$ and 178r, dated end of Rajab 818/early October 1415. In it, he provided a list of the sessions which he took part in in Fez in 810/1410, after which he obtained an ijāza for the 'three works of hadìth'. Qāḍī 'Iyāḍ (d.544/1149) K. al-Shifä’48 and al-Būṣīì̄'s (d. 694/1294) Burda, ${ }^{49}$ also mentioned in the certificate, could have been studied in Bona during the return trip in 1415. In the final paragraph, he indicated that he had received an ijāza from Ibn Marzūq for two works authored by the latter, a commentary on Khalil's Mukhtașar, and the Șidq al-mawadda 'alà al-Burda.

Then follows a text written by Ibn Marzūq (fol. 178r): first of all, he confirmed the previous comments and made a list of works that he had either written, started to write, or simply planned to write, and which he authorised his disciple to transmit. In a way, the certificate completed the circle of the intellectual and real-life journey of our scholarly traveller, who appeared to have taken advantage of this encounter to include the ijāza obtained five years earlier in 810/1410 in the volume constituting the chronicles of his knowledge. Continuing the path westwards, Muhammad b. 'Abd al-'Azīz reached Bougie. A collation note attests to his presence in the city at the beginning of Ramadān 818/November 1415 (fol. 148r, in the margin).

After returning to Meknes, Muhammad b. 'Abd al-'Azīz continued to use the spaces that remained blank in the miscellany to write down personal notes. In $R a b i ̄$ ' II 820/May-June 1417, he copied the text of a qașida that he had written, and that he had read in Damascus (fol. 175v). Later, he once again travelled to Granada in $824 / 1421$, the memory of which he preserved by inserting two short, partially erased lines into fol. $5 \mathrm{r}$. On fol. 203v and 204r, notes related to observations of the sun and the moon, made between $831 / 1428$ and $840 / 1437$, bear witness to his activity up until that date. ${ }^{50}$

46 It is the text no. 8, see above n. 13. The certificate has been written on the recto of the folio where the copyist had transcribed this treatise five years earlier.

47 See n. 29.

$48 G A L$ I, 369; $S$ I, 630.

$49 G A L$ I, 264; $S$ I, 467.

50 If such is the case, his death that is reported to have occurred during a second trip to the East would have taken place after 840/1437 (see Ibn Zaydān 2008, 689). 


\section{A princely compendium}

The second manuscript, which is Arabe no. 248 (Figs 5-6) in the collection from El Escorial, takes us in another direction, irrespective of the years that separate the two volumes. It is a beautiful quarto copy that consists of $385219 \times 157 \mathrm{~mm}$ folios which are protected by a good quality binding that was decorated with blind tooling. ${ }^{51}$

From the outside, this volume stands out by the title that appears on the edge-the bottom edge in this case-as was customary in the Islamic world. However, the care given to writing this title in calligraphy distinguishes it from what we commonly find in this region. In fact, the short text is written in an elaborate variant of maghribi, with a few exclusively decorative elements intended to best occupy the available space. The title is significantly more elaborate than those usually found on the upper or lower edges, but it was admittedly difficult to account for the contents of the manuscript.

The colophons provide no information on the copyist or the place of the copying, but they do give two dates: on fol. 281r, we find an intermediate colo-

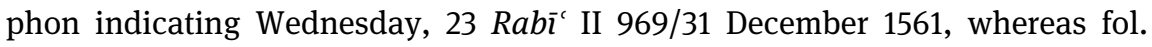
385 r, the last folio of the manuscript, indicates that the latter was completed on Monday, 17 Șafar 968/7 November 1560 (Fig. 6). ${ }^{52}$ The anteriority of the latter is surprising and seems to indicate that the transcription was done in multiple stages, possibly by different individuals. Regarding the collation, it was completed on 25 Rajab 968/11 April 1561, as indicated by a note in the margin on the same fol. 385r, to which we will return. A fourth date, 12 Ramadān 969/16 May 1562 , appears in a document placed at the beginning of the volume. It confirms the previous dates, yet does not shed light on the chronology of the transcription, which therefore took place during the reign of Saadian Sultan 'Abd Allāh al-Ghālib (r. 1557-1574).

51 See Dérenbourg 1884, 151-153.

52 And not 970/1562 as stated by Dérenbourg 1884, 153. Also see Déroche 2014. 


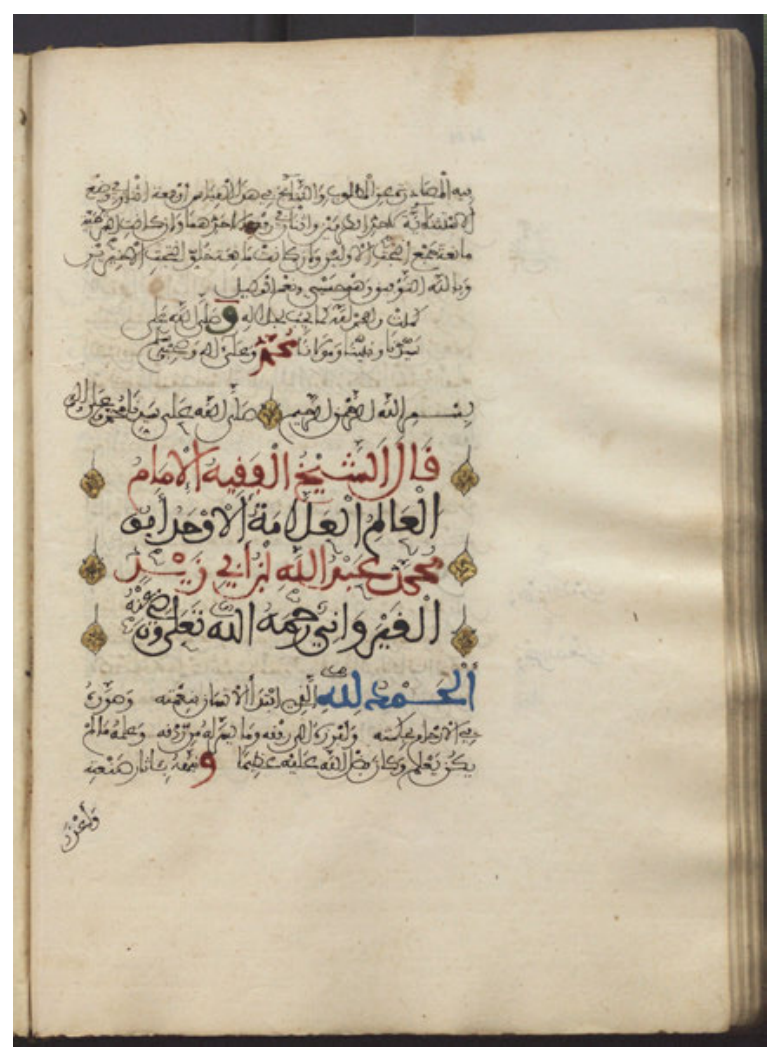

Fig. 5: Arabe 248, fol. 44v (C) El Escorial

The copy was written with care, in an average-sized hand, with 19 lines per page. The paper of Western make is homogenous, but the sheets are often isolated: the quires also show multiple stubs, which explains why the back is thicker than the fore-edge. Two misțara were used to rule the folios, one for long lines and the other to transcribe verses. Wide margins were set aside around the writing area, in which annotations were sometimes made (in particular on fols $327 \mathrm{v}$ to $334 \mathrm{v})$. The beginnings of texts are signalled by the choice of larger characters and, above all, by the use of coloured inks, including red and often also blue, combined with the ink used for the remainder of the text (Fig. 5). The high level of the writing and the page layout clearly indicate that this is a quality copy.

The structure of the quires reflects the extent to which the production of this volume was different from that of manuscript Arabe 788. 


\begin{tabular}{|c|c|c|c|c|}
\hline Quires $^{53}$ & Text No. & Begins at & Ends at & Remarks \\
\hline 1 fol. added & & & & $16 / 05 / 1562$ \\
\hline \multirow[t]{2}{*}{ IV (9) } & 1 & $2 v$ & $7 r$ & \\
\hline & 2 & $7 \mathrm{v}$ & & \\
\hline \multirow[t]{5}{*}{$2 \mathrm{~V}(29)$} & & & $11 \mathrm{v}$ & \\
\hline & 3 & $12 r$ & $24 \mathrm{v}$ & \\
\hline & 4 & $24 \mathrm{v}$ & $28 r$ & \\
\hline & 5 & $28 r$ & $30 r$ & \\
\hline & 6 & $30 v$ & & \\
\hline \multirow[t]{2}{*}{$V+1(40)$} & & & $35 v$ & \\
\hline & 7 & $35 \mathrm{v}$ & & \\
\hline \multirow[t]{6}{*}{23 V (290) } & & & $44 \mathrm{v}$ & \\
\hline & 8 & $44 \mathrm{v}$ & $107 v$ & \\
\hline & 9 & $108 v$ & $250 \mathrm{r}$ & fol. $108 \mathrm{r}$ blank \\
\hline & 10 & $250 v$ & $281 r$ & $\begin{array}{l}\text { colophon dated } \\
31 / 12 / 1561\end{array}$ \\
\hline & 11 & $281 v$ & $287 r$ & \\
\hline & 12 & $287 v$ & $290 v$ & \\
\hline 3 V (320) & 13 & $291 v$ & $303 v$ & fol. $291 \mathrm{r}$ blank \\
\hline III (326) & 14 & $304 r$ & $326 v$ & $\begin{array}{l}\text { colophon without } \\
\text { date }\end{array}$ \\
\hline \multirow[t]{3}{*}{$6 \mathrm{~V}(386)$} & 15 & $327 v$ & $368 v$ & fol. $327 \mathrm{r}$ blank \\
\hline & 16 & $369 r$ & $374 v$ & \\
\hline & 17 & $374 v$ & $385 r$ & $\begin{array}{l}\text { colophon dated } \\
7 / 11 / 1560\end{array}$ \\
\hline
\end{tabular}

As Hartwig Dérenbourg has previously pointed out in the collection catalogue, the contents of the manuscript are the result of one initial decision..$^{54}$ Despite the chronological problem indicated above, the texts demonstrate a high degree of homogeneity in their presentation-even though it is not possible to exclude the possibility of joint work by two copyists-and frequently overlap quires. Fol. 250 bears witness to this: its recto contains the explicit of text no. 9, of a legal nature, whereas the incipit of text no. 10, a grammar treatise, appears on its verso, clearly evidencing continuity in the transcription. However, the analysis of the

53 See n. 4.

54 Dérenbourg 1884, 153. 
structure of quires reveals two locations where an interruption may have taken place, namely after fols 290 and 326. Both of these folios are the last of a quinion. In both cases, the text that follows (no. 13 for one, no. 15 for the other) begins on the verso of the next quire (fols $291 \mathrm{v}$ and $327 \mathrm{v}$ ), which is the rule in the Islamic manuscript tradition, although it is true that certain rules are broken in this volume (nos 3, 5, 14, and 16 start on the recto side). Therefore, this may not constitute a strong argument in favour of an interruption after fol. 290, no more than the three rectos left blank (fols 108r, 291r and 327r) do, which coincide twice with the beginning of a quire (fols 291r and 327r), while the third is found in the middle of a quinion. The undated colophon on fol. $326 \mathrm{v}$ could mark an interruption in the copying, whereas that of fol. 281r is found on the recto of the second folio of a quire. The strongest argument in favour of an interruption at fol. 326 is the type of quire in which the undated colophon appears: it is an unusual ternion that is a unique and surprising example of this type of quire within a volume that almost exclusively consists of quinions.

It would therefore be necessary to distinguish two stages in the production, from fol. 2 to fol. 326, and from fol. 327 to fol. 385. What should we make of the date of the colophon on fol. 385r, which would indicate that the last text in the volume was the first to have been written? Or, must we assume that this is a mistake the copyist made, who may have traced an eight rūmī numeral instead of nine? In any event, even if we read 969 instead of 968, 27 October 1561 is prior to the first colophon of 31 December of the same year.

As in Arabe 788, the works are arranged on the basis of a clear thematic structure. The book is designed for ease of use: a table of contents appearing on fol. 2 presents the titles in four columns, sometimes followed by the name of the author. Each of the columns contains four rows, except for the first one, which contains five. The final colophon gives a summary of the manuscript's contents, listing the subjects of the collection (called dīwān here) and emphasizing the deliberate nature of the operation. Coloured bookmarks integrated into the paper of the first folio of each text afford easier access to them, as in Arabe 788.

1. 2v-7r: Abū 'Abd Allāh Muhammad b. Sa Sāid al-Dūlāsī al-Būṣīīi (d.694/1294), alBurda. ${ }^{55}$

2. 7v-11v: Șafî al-dīn 'Abd al-'Azīz b. Sarāyā al-Ḥillī (d.750/1349), Kāfiyya fi albadī'iyya. ${ }^{56}$

55 See GAL I, 264; $S$ I, 467.

56 See GAL II, 160; $S$ II, 199. In the table of contents (fol. 2r), there is only the name of the author. 
3. 12r-24v: Abū 'Abd Allāh Muḥammad b. Yūsuf al-Ḥasanī al-Sanūsī (d. 892/1486), 'Aqīda ahl al-tawhīd also al-'Aqīda al-kubrā.57

4. 24v-28r: al-Sanūsī, Umm al-barāhin also al- 'Aqīda al-ṣugrā. ${ }^{58}$

5. 28r-30r: al-Sanūsī, tracts of the same kind. ${ }^{59}$

6. 30v-35v: al-Sanūsī, al-Isāghugī. ${ }^{60}$

7. $35 \mathrm{v}-44 \mathrm{v}$ : al-Sanūsī, Theological treatise. ${ }^{61}$

8. 44v-107v: Abū Muḥammad 'Abd Allāh b. Abī Zayd al-Qayrawānī (d. 386/996), K. alrisāla. ${ }^{62}$

9. 108r-250r: Khalīl b. Ișhāq b. Mūsā al-Mālikī al-Miṣrī (d. 767/1365), al-Mukhtașar. ${ }^{63}$

10. 250v-281r: Jamāl al-dīn Muhammad b. 'Abdallāh b. Muḥammad b. 'Abdallāh Ibn Mālik al-Ṭā'ī al-Jayyānī (d. 672/1273), al-Alfiyya (part). ${ }^{64}$

11. 281v-287r: Abū 'Abd Allāh Muḥammad b. Muḥammad b. Dā'ud al-Ṣanhājī b. Ajurrūm (d. 723/1323), Ajurrūmiyya. ${ }^{65}$

12. 287v-290v: Ibn Mālik, Lāmiyya al-af'āl (or al-miftāḥ fi abniya al-af'āl). ${ }^{66}$

13. 291v-303v: Abū al-'Abbās Aḥmad b. Abī 'Abd Allāh Muḥammad b. 'Uthmān al-Azdī al-Maghribī, known as Ibn al-Bannā (d. 721/1321), Talkhịs a māl al-hisāāb. ${ }^{67}$

14. 304r-326v: Abū Isḥāq Ibrāhīm b. Abī Bakr al-Tilimsānī, urjūza about rhetoric and style. ${ }^{68}$

15. 327r-368v: Jamāl al-dīn Muḥammad b. 'Abd al-Raḥmān al-Qazwīnī (d. 739/1338), Talkhīṣ al-miftāh. ${ }^{69}$

16. 369r-374v: Diyā al-dīn abū Muhammad 'Abdallāh b. 'Uthmān al-Khazrajī (fl. towards 650/1252), al-Rāmiza al-shāfiyya fì 'ilm al- 'arūḍ. ${ }^{70}$

57 See GAL II, 250 (I). On the importance of this author and the reception of his work in the East, see Kh. El-Rouayheb, Islamic intellectual history in the seventeenth century. Scholarly currents in the Ottoman Empire and the Maghreb, Cambridge, 2015, p. 131-147 or 188-200.

58 GAL II, 250 (II).

59 I have been unable to identify these texts in the list of the works of al-Sanūsī published by Brockelmann (S II, 356). In the table of contents (fol. 2r), the title is given as al-Muqaddima.

60 In the table of contents (fol. 2r), the name of the author has been added; I assume that Burhān al-Dīn al-Biqā'î̀ (d. 1480) is meant here.

61 I have been unable to identify this text in the list of the works of al-Sanūsī published by Brockelmann (S II, 356).

62 See $G A L$ I, 177; $S$ I, 301.

63 Text no. 2 in MS Arabe788, see n. 6.

64 Text no. 9 in MS Arabe 788, see n. 14.

65 See GAL II, 237; $S$ II, 332.

66 See GAL I, 300; $S$ I, 256.

67 Text no. 19 in MS Arabe 788, see n. 23.

68 In the table of contents on fol. 2r, the title appears as: al-Tilimsāniyya.

69 Text no. 5 in MS Arabe 788, see n. 9. In the table of contents (fol. 2r), it is the only case with the Burda (no 1) of a title without the name of the author. 
17. 374v-385r: Abū Zayd 'Abd al-Raḥmān al-Jādirī/al-Jādarī Abū Zayd 'Abd al-Raḥmān b. Muhammad b. 'Ațiya al-Maydūnī al-Jādirī (d. 818/1416), Rawḍa al-azhār fi 'ilm waqt al-layl wa-l-nahār. ${ }^{71}$

The contents of the manuscript are particularly interesting, due to the coincidences that can be observed between it and al-Fishtālī's statement regarding the education that the Saadian Sultan Ahmad al-Manșū ${ }^{72}$ received-information repeated in a somewhat summarized manner by al-Ifrānī in his Nuzhat. ${ }^{73}$ The list starts by indicating that the future ruler had initially learnt the Qur'ān prior to studying the two legal texts that appear in the miscellany from El Escorial, al-Qayrawānī's Risāla, and Khalil's Mukhtașar, and then the grammar treatises, the Ajurrümiyya, Ibn Mālik's Alfiyya, and Lāmiyya al-af'āl by the same author. Without going into further detail, al-Fishtālī mentions that Aḥmad al-Manșūr had studied arithmetic before moving on to texts of a religious nature: first, and without more details, the ușūl al-dīn, followed by al-Kubrāa, a commentary on al-Sanūsì's șughrā and alIsāghugī as well as al-Mukātibī's Shamsiyya fi al-manțiq, ${ }^{74}$ along with the short and long commentaries on Ibn Zikrī’s qașìda (al-Ifrānī indicates the Mulkhịs almaqūssid). The last works cited in this list are al-Khazrajì's al-Khazrajiyya, alSa'ad's Mukhtașar, and al-Qazwīnīs Talkhịs al-miftāh. The following section in alFishtālī's text concerns the hadìth and the fiqh, and then presents the subsequent readings of the future sultan.

The coincidence between the educational programme detailed by al-Fishtāli and the contents of the manuscript is striking. It confirms the existence of a corpus of educational texts classified within the manuscript according to an order of precedence, including theology, law, grammar, rhetoric, and poetry. The presence of arithmetic within this group is significant and represents an interesting convergence between the two MTMs Arabe 248 and 788.

70 Text no. 11 in MS Arabe 788, see n. 16.

71 Also see above.

72 Al-Fishtālī 1964, 188-189.

73 Al-Ifrānī 1889, 216-217; Nuzhat al-nādī 2010, 209-211.

74 The name of the author is indicated in al-Fishtālī 1964, 190, but al-Ifrānī’s editor, al-Shadilī, states in a note that he is 'Alī b. 'Umar al-Qazwīnì (Nuzhat al-hādī 2010, 210, n. 17). 


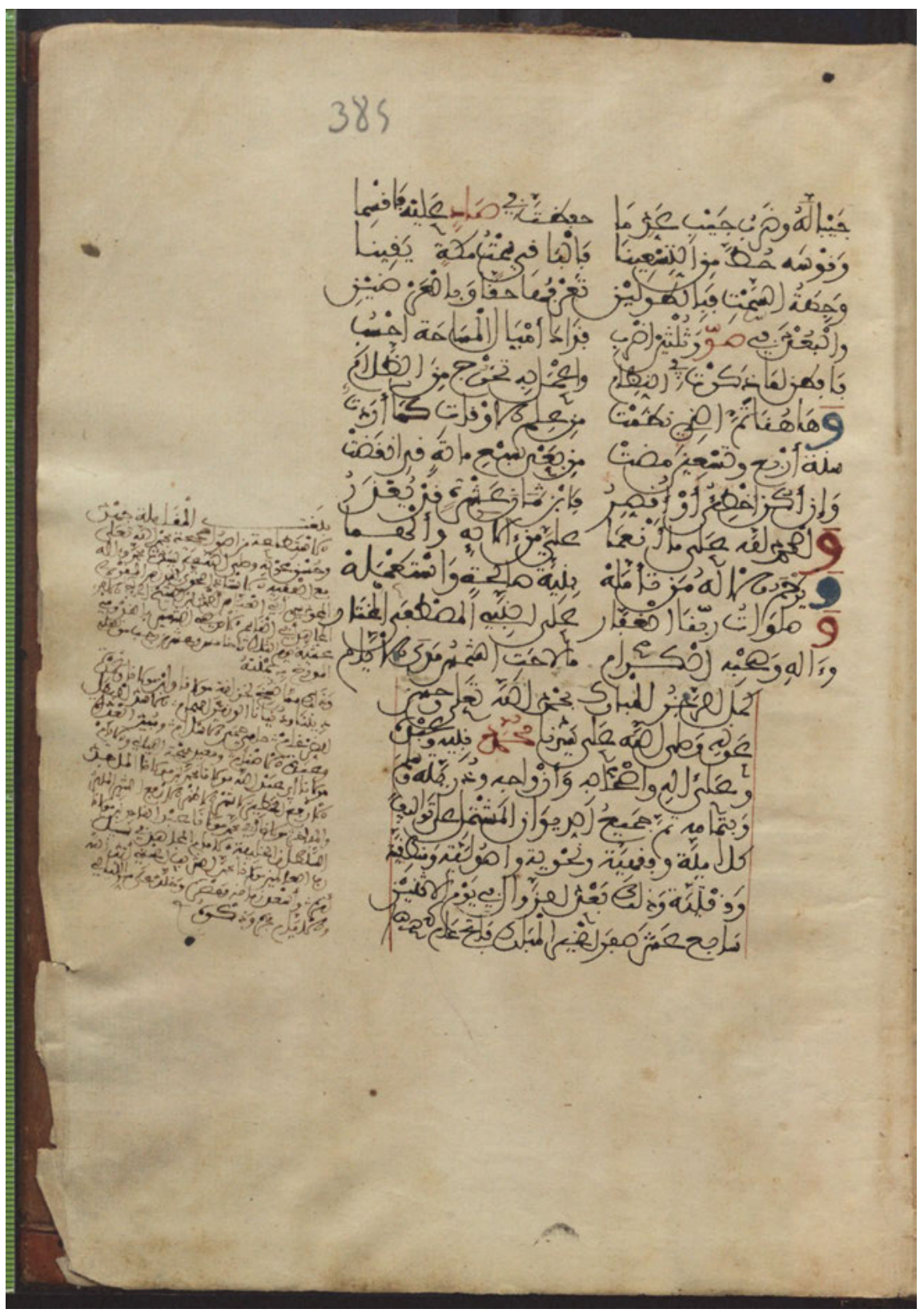

Fig. 6: Arabe 248, fol. 385r. Collation note. ( El Escorial 
The creator of Arabe 788 is well identified. What about the other volume? Two texts provide relevant information. The first, the collation note from fol. $385 \mathrm{r}$ (Fig 6), is the clearest. The scribe, who may be the copyist (or one of the copyists) of the manuscript, indicated that the volume was prepared for the library of the vizir Abū 'Abd Allāh Muhammad b. 'Abd al-Qādir b. Muḥammad al-Sharīf alHasanì. The date and name lead us to believe that the person who commissioned the manuscript was a nephew of Sultan 'Abd Allāh al-Ghālib, who had the nephew killed in 975/1567. ${ }^{75}$ Muhammad b. 'Abd al-Qādir's father was one of the sons of Sultan Muhammad al-Shaykh. Around 1560, Muhammad b. 'Abd al-Qādir was most likely no longer a student when he occupied official public positions in the service of his uncle. The manuscript probably served to provide him with convenient access to the texts constituting the knowledge of pre-modern Morocco's cultured elite. The large extent to which the contents of the MTM correspond with that of the 'curriculum' described by al-Fishtāli speaks for itself. We can assume that the prince probably did not have to bother about selecting the works; the collation note records the assistance of a traditional scholar, Abū al-'Abbās Aḥmad b. Abī al-Qāsim al-Idrīsī, known as al-Qaddūmī (992/1584), ${ }^{76}$ who verified the accuracy of the texts but may also have based the selection on established 'foundational knowledge'. An ijāza dated 12 Ramaḍān 969/16 May 1562 also concerns Muhammad b. 'Abd al-Qādir al-Ḥasanī, who is both its beneficiary and its copyist. It contains a transmission chain (isnād) whose different stages, introduced by the verb șāfaḥa, go back to 'Alī b. Abū Ṭālib-including the main figures of Islamic mysticism, such as Abū Midyan, Ibn al-'Arabī, Abū Ḥāmid al-Ghazālī or even hasan al-Bașrī.

The mystical dimension is not completely absent from manuscript Arabe 788, but its presence is enhanced in manuscript Arabe 248 through devotional readings. These do not pertain to a strictly educational framework, but rather reflect the importance taken on by worship of the Prophet, the origins of which, associated mainly with the Kitāb al-shifā by Qāḍi 'Iyāḍ (d.544/1149), date back to the twelfth century. In the specific context of Morocco during the latter half of the sixteenth century, the decision to start with al-Būsinirìs very famous poem, the Burda (fols 2v-7r), and to follow it with șafì al-dīn al-Ḥillī's Kāfiyya fi al-badì'iyya (fols $7 \mathrm{v}-11 \mathrm{v}$ ), can be understood in terms of the central place given to this devo-

75 See Fagnan 1924, 388 (= Anonyme sur la dynastie sa'dienne); Le Tourneau 1977, 26. However, another date of his death is found there (ibid., 25, n. 71). Another person with the same name is also mentioned in the sources, but he is an 'alawī sharif living in southern Morocco; it is therefore unlikely that he is the owner of the Escorial manuscript (Fagnan 1924, 347).

76 See Hajji 1976, II, 414. 
tion in Sufi movements and in popular worship of the time, and by the political dimension that the worship of Muhammad took on with the advent of a dynasty laying claim to a sherifian origin. Yet, contrary to what might be expected, the Dalā'il al-hayrāt, whose author al-Jazūlī held an important place in Saadian ideology, was not chosen at this point. ${ }^{77}$ Manuscript Arabe 788, on the other hand, conceived in another setting, integrates devotional texts in a different way.

Separated by a bit more than a century, the two MTMs Arabe 248 and 788 from El Escorial enable us to account more fully for the features and wealth of MTMs in the Arabic manuscript tradition. In both cases, there is detailed knowledge concerning the circumstances of their creation. This allows us to avoid mistakes when interpreting their content, which in both cases was part of a specific undertaking. That of Muhammad b. 'Abd al-'Azīz al-Ṣanhājī pertains to a long tradition of travel 'in quest of knowledge', seeking masters whose authorizations would come to have a place in the book alongside the texts that they concerned, thus fully certifying the knowledge therein. However, Muhammad b. 'Abd al-'Azīz al-Ṣanhājī's learning strategies were even more ambitious. The authorizations granted to him are testament to this ambition: thirty certificates for twenty-three works were obtained, but a large number of these do not appear among the works transcribed in the manuscript. The manuscript is an essential witness to and guarantee of Muhammad b. 'Abd al-'Azīz al-Ṣanhājì's knowledge, containing twenty-six texts he wrote in his own hand, then the certificates added afterwards on various folios of the manuscript and referring to fifteen works he did not write but studied with different teachers. Despite its somewhat disorganized appearance, this volume actually serves as a fahrasa, a well-known genre in the Western part of the Muslim world, where scholars listed their masters, the works that they received from them, and their isnad-s. However, in the case at hand, copies of certain works being present add another dimension to the manuscript: the MTM is 'double', at the interface between the written and the oral, between recording on paper and memorization, and us representing a complex approach to knowledge.

On the other hand, the sole purpose of the prince's MTM was to serve as the bedside book of an 'honest man', although it contains texts that were already of interest to the scholar who prepared the other book, Muhammad b. 'Abd al-'Azīz al-Ṣanhāìi: one in the domain of the fiqh (Khalīl's Mukhtașar), three in the domain of grammar and rhetoric (Ibn Mālik’s Alfiyya, al-Qazwīnī’s Talkhīṣ al-miftāh, and Diyā al-dīn abū Muhammad 'Abdallāh b. 'Uthmān al-Khazrajī's al-Rāmiza alshāfiyya fì 'ilm al-'arūẹ), and last of all, one mathematics treatise (Talkhīs fì alhis $\bar{a} b$ by Ibn al-Bannā'). The organisation of the two manuscripts is different: the

77 See Abid 2017. 
Saadian one, created for a prince, gives more space in the first section to holy readings and religion, while placing three short treatises on logic immediately afterwards. The fiqh section is practically identical in the two collections, whereas grammar takes up more space in manuscript Arabe 248, where rhetoric comes later, following the arithmetic treatise by Ibn al-Bannā'. It appears that prosody was of greater interest to Muhammad b. 'Abd al-'Azīz, but it is above all the scientific portion that he developed to a greater extent, even though the Saadian MTM ends with an applied astronomy work similar to that appearing in Arabe 788. The use of these two manuscripts differs, if anything due to the time period during which they remained in the hands of their first owner: Muhammad $b$. 'Abd al-'Azīz was able to make use of his manuscript for almost thirty years, whereas the Saadian prince kept his volume for only six years. The former multiplied the notes, whereas the latter only did so occasionally, such as on fols $327 \mathrm{v}$ to $334 \mathrm{v}$-assuming that these notes were actually written by him. Arabe 248 from El Escorial constitutes a first-class testimony to the culture of the Moroccan elite during the second half of the sixteenth century, although the convergence between the two manuscripts emphasizes the continuity of the intellectual history of fifteenth- and sixteenth-centuries Morocco-and beyond.

\section{References}

Abid, Hiba (2017), Les Dalāil al-Khayrāt d'al-Jazūlī (m. 869/1465). La tradition manuscrite d'un livre de prières soufi au Maghreb du Xe/XVIe au XIII'/XIXe siècles (unpublished doctoral thesis, EPHE, May 2017).

Abū Rayya, 'Ațā / al-Asmarī, Sulțān (eds) (2006), Ibn Ghāzī al-Miknāsī, al-Rawọ al-hatūn fĩ akhbār Miknāsat al-Zaytūn. Cairo: Maktabat al-Taqāfah al-dīnīya.

Al-Harrāma, 'Abd al-Ḥamīd (ed.) (2000), Aḥmad Bābā al-Tunbuktī, Nayl al-ibtihāj bi-taṭrīz aldībāj. Tripoli.

Al-Ifrānī (1889), Nozhet-elhadi. Histoire de la dynastie saadienne au Maroc (1511-1670) par Mohammed Esseghir ben Elhadj ben Abdallah Eloufrani, transl. Houdas, Octave Victor, Paris: Ernest Leroux.

Al-Shadilī, 'Abd al-Lațīf (ed.) (2010), al-Ifrānī, Nuzhat al-hādī wa-turfat al-ḥādī fĩ man bi-lMaghrib min ahl al-qarn al-ḥādī. Rabat.

'Alī, 'Umar (ed.) (2008), Ibn Zaydān, Itḥāa a'lām al-nās bi jamāl akhbār ḥāẹirat Miknās. Cairo: Maktabat al-Taqāfah al-dīnīya.

Benchekroun, Mohamed (1974), La vie intellectuelle marocaine sous les Mérinides et les Watțāsides (XIII XIV XVe XVI siècles), Rabat: [s.n.].

Dérenbourg, Hartwig $(1884,1903)$, Les manuscrits arabes de l'Escurial. II, Fascicule I, Les manuscrits arabes de l'Escurial. Paris: Ernest Leroux.

Déroche, François (2014), 'Des miscellanées princières d'époque saadienne. Le manuscrit 248 de la bibliothèque de San Lorenzo de l'Escorial', in Nicolas De Lange / Judith Olszowy- 
Schlanger (eds), Manuscrits hébreux et arabes: Mélanges en l'honneur de Colette Sirat. Turnhout: Brepols, 163-174.

$E I^{2}=$ Encyclopedia of Islam, $2^{\text {nd }}$ edn : Middle East and Islamic Studies, edited by P. Bearman, Th. Bianquis, C.E. Bosworth, E. van Donzel and W.P. Heinrichs 12 vols. with indexes, etc., Leiden: E. J. Brill, 1960-2005.

Fagnan, Edmond (1924), Extraits inédits relatifs au Maghreb (géographie et histoire), traduits de l'arabe et annotés. Alger: Ancienne maison Bastide-Jourdan, Jules Carbonel.

Gacek, Adam (2009), Arabic Manuscripts. A Vademecum for Readers. Leiden, Boston: Brill.

$G A L=$ Brockelmann, Carl $(1898,1902)$, Geschichte der Arabischen Litteratur, I-II, Weimar:

Felber.

Gannūn, 'Abdallah A. (ed.) (1964), Al-Fishtālī, Manāhil al-ṣafā fi akhbār al-mulūk al-shurafä'. Rabat.

Hajji, Muhammad (1976), L'activité intellectuelle au Maroc à l'époque sa'dide, II. Rabat: Dal El Maghrib.

Le Tourneau, Roger (1977), 'Histoire de la dynastie sa'dide. Extrait de al-Turğumān al-mu'rib 'an duwal al-Mašriq wal Mag̉rib d'Abū al-Qāsim b. Aḥmad b. 'Ali b. Ibrāhīm al-Zayyānī... Texte, traduction et notes présentés par L. Mougin et H. Hamburger', in Revue de l'Occident musulman et de la Méditerranée, 23/1: 7-109.

$S=$ Brockelmann, Carl (1937, 1938, 1942), Geschichte der Arabischen Litteratur. SupplementBand, I-III. Leiden: Brill.

Viguera, María Jesús (1977), Ibn Marzūq. El Musnad : hechos memorables de Abū l-Hasan sultan de los Benimerines. Estudio, traduccion, anotacion, indices anotados. Madrid: Instituto hispano-árabe de cultura. 
